\title{
Take a Cox-2 and call me in the morning...really?
}

\author{
Elizabeth A. David, MD, MAS
}

\author{
From the Division of Thoracic Surgery, Department of Surgery, Keck School of Medicine, University of Southern \\ California, Los Angeles, Calif. \\ Disclosures: Author has nothing to disclose with regard to commercial support. \\ Received for publication Nov 13, 2018; accepted for publication Nov 14, 2018; available ahead of print Jan 7, \\ 2019. \\ Address for reprints: Elizabeth A. David, MD, MAS, 1510 San Pablo St, HCC 1, Suite 514, Los Angeles, CA \\ 90033 (E-mail: Elizabeth.David@med.usc.edu). \\ J Thorac Cardiovasc Surg 2019;157:e199 \\ $0022-5223 / \$ 36.00$ \\ Copyright (C) 2018 by The American Association for Thoracic Surgery \\ https://doi.org/10.1016/j.jtcvs.2018.11.053
}

Kaiho and colleagues have presented a novel case in The Journal, and I will fully admit that when I was asked to review the manuscript that I was highly skeptical of its merits simply because it was a case report. But I set my own bias aside and started to read. I'm not sure if it was post-traumatic stress disorder from complicated reoperative resections for desmoid tumor that I participated in during my training and a desire to avoid that type of post-traumatic stress disorder in the future, or the dramatic results presented by the authors, but I found this case very novel yet applicable to practice.

The authors report a case of recurrent desmoid tumor that was successfully treated with meloxicam only based on the presence of a catenin beta 1 gene mutation in the tumor. ${ }^{1}$ On review of the imaging, the team was able to avoid a morbid, reoperative resection for the patient that would have involved resection of multiple ribs and a complicated reconstruction. The results with meloxicam treatment were quite durable as well, with a 4-year disease-free interval reported. The authors suggest that the presence of the somatic mutation type of the CTNNB1 gene may be a good biomarker for efficacy of treatment with meloxicam.

My skepticism about the scientific merits of this case report persisted until I consulted PubMed and started reading through the 24 citations listed for "Cox-2 and desmoid." 2-4 I was surprised to see several other case reports detailing nonthoracic desmoids and their excellent response to therapy with Cox-2 inhibitors. There was one particularly interesting case in which a $10-\mathrm{cm}$ pancreatic

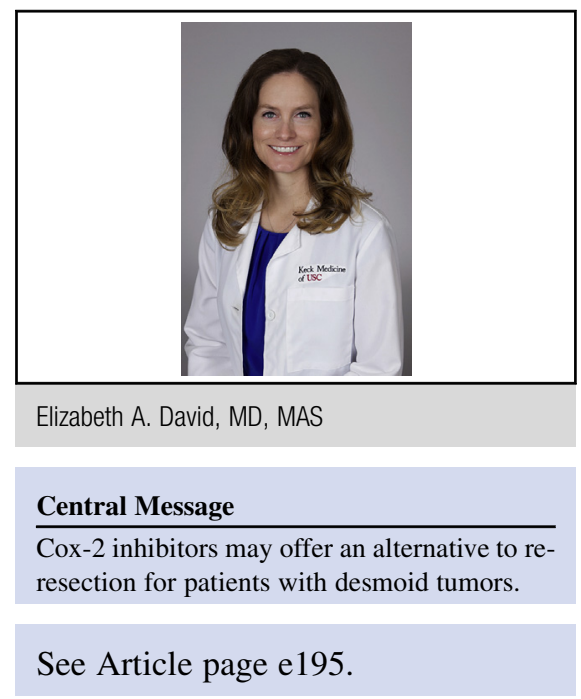

head desmoid tumor showed no recurrence for 24 months with adjuvant Cox-2 inhibitor treatment. ${ }^{3}$ Clearly, more data are needed before widespread use, but for these rare tumors, these cases are compelling and this management should be considered when contemplating a morbid resection of recurrent desmoid tumor. It's not quite "take a Cox-2 and call me in the morning," but maybe someday.

\section{References}

1. Kaiho T, Nakajima T, Nishida Y, Yoshino I. Successful treatment of a recurren chest wall desmoid tumor with COX-2 inhibitors. J Thorac Cardiovasc Surg. 2019;157:e195-7.

2. Yang S, Wang X, Jiang H, Wang Y, Li Z, Lu H. Effective treatment of aggressive fibromatosis with celecoxib guided by genetic testing. Cancer Biol Ther. 2017;18: 757-60.

3. Wang Y-C, Wong J-U. Complete remission of pancreatic head desmoid tumor treated by COX-2 inhibitor-a case report. World J Surg Oncol. 2016;14:190.

4. Sakai T, Nishida Y, Hamada S, Koike H, Ikuta K, Ota T, et al Immunohistochemical staining with non-phospho beta-catenin as a diagnostic and prognostic tool of COX-2 inhibitor therapy for patients with extra-peritoneal desmoid-type fibromatosis. Diagn Pathol. 2017;12:66. 